\title{
PATIO AS A STRUCTURAL INVARIANT. BUILDINGS WITH PATIO FACING ADAPTIVE REUSE IN BARCELONA
}

\author{
PERE FUERTES ${ }^{1}$, ROGER SAUQUET ${ }^{2}$, NÚRIA SALVADÓ ${ }^{3}$ \\ ${ }^{1}$ Department of Architectural Design, Universitat Politècnica de Catalunya \\ Av. Diagonal, 649, pl. 5. 08028 Barcelona, Spain \\ e-mail: pere.fuertes@upc.edu,web page: habitar.upc.edu \\ 2 Department of Architectural Design, Universitat Politècnica de Catalunya \\ Av. Diagonal, 649, pl. 5. 08028 Barcelona, Spain \\ e-mail: roger-joan.sauquet@upc.edu,web page: habitar.upc.edu \\ ${ }^{3}$ Department of Architectural Design, Universitat Politècnica de Catalunya \\ Av. Diagonal, 649, pl. 5. 08028 Barcelona, Spain \\ e-mail: nuria.salvado@upc.edu,web page: habitar.upc.edu
}

Keywords: Patios, Structuring Patios, Architectural Renewal, Adaptive Reuse, Life-Cycle, Barcelona

\begin{abstract}
Certain architectural structures have the ability to persist over time when a building undergoes a change of use. This is the case of patios, according to the conclusions of a study focused on the reused buildings of Barcelona recently developed. The survey of this architectural element should enable us to better understand the behaviour of these buildings.

If we define the open-air inner courtyard of a building as a patio, this study is especially interested in those who have the capacity to organize spaces, systematize circulations along with stairs and corridors - and configure the building as a whole. This set of structuring patios particularly applies in a dense city like Barcelona because their position and size also provide liveability to interior rooms. In light of these qualities, such patios can be regarded as an essential piece of both the formal and the bearing structure of a building.

The location and attributes of these patios can be associated with the potential for adaptive reuse: they can help achieve a lower impact on the architectural and formal structure of a renovated building, when used appropriately. Hence the patio can be seen as an indicator of how a new programme adapts to the existing support. 171 out of 565 buildings documented and analysed in Barcelona - a thirty percent of the overall - have at least one patio of a kind whose characteristics have outlived one or more renovation processes. The percentage rises to $50 \%$ in Ciutat Vella and Eixample districts, where density and architectural typology make them particularly relevant.

Buildings with patios match different uses and periods from the 11th to the 20th century. In spite of the expected differences, the studio draws conclusions on the understanding of material transformations and changes of use they have undergone.

In short, with regard to buildings included in this category - both heritage and common ones - this paper helps verify the hypothesis that the very existence of a patio is responsible for the persistence of the internal arrangement and structure and must be carefully considered in future interventions when addressed to extend the life-cycle of a building.
\end{abstract}




\section{INTRODUCTION}

The 2013 call for proposals of the Spanish National R\&D Programme Aimed at the Challenges of Society resulted in a study on the reused buildings in the city of Barcelona, which concluded with the publication of an Atlas del aprovechamiento arquitectónico, estudio crítico de los edificios reutilizados en Barcelona [1], hereinafter Atlas. This research, carried out by the Habitar UPC group, revealed the extent of the phenomenon of change of use in the city of Barcelona and, among other conclusions, brought to light the importance of the patio, not only as a structural and structuring element of the functionality and use of a building, but also in its preservation, durability, evolution and transformation over time, that is, in its adaptive capacities for reuse.

The concept of adaptive reuse - as a sustainable strategy to extend the life of a building considered as a resource - constitutes a consistent corpus of research that has been intensively developed in recent decades. If, the literature on this concept can be initially associated with the transformation of heritage buildings [2], the logical evolution of the term has expanded to the capacity to value any building susceptible of being adapted to a new use and to the particular conditions of the necessary transformation process $[3,4,5,6,7]$.

In this sense, the Atlas considers built architecture and the urban environment as a resource that can be triggered when the life cycle of buildings is strategically addressed; a resource that allows the generation of urban habitability by taking maximum advantage of what already exists and minimizing the need to consume more territory. In the consolidated city, where the

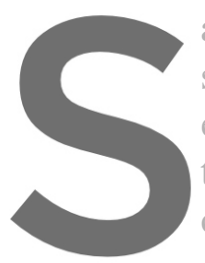
availability of space is sustainable alternative to essential to identify the to analyse the capacity change of use. Therefor existing architectural support and the proposedi
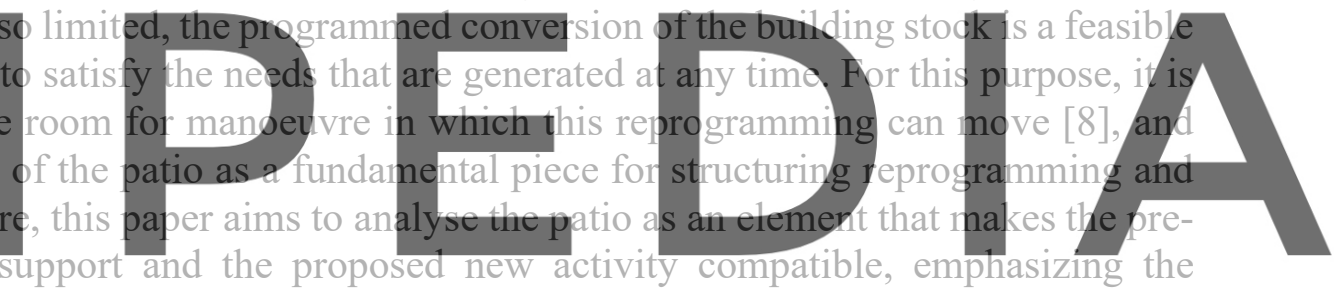
attributes of both the container and the new contents

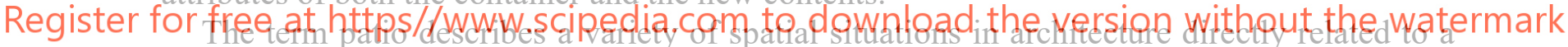

building's inner courtyard, usually in the open air or under a skylight. The patio - whose main task is to provide light and aeration to the interior areas of a building - plays various roles depending on its scale, shape, character and use. We can identify as patios cloisters, backyards, courtyards of public buildings, patios of palaces and private houses, peristyles, atriums, or air yards [9].

Beyond this wide spectrum of situations, the archetypal patio considered here is one whose purpose is not only to illuminate and aerate, but also to structure a building, linking the different parts that constitute it. Thus, the patio can be identified as the 'main room' of the house, a piece without a roof that organises space and activity around it. Its character is that of an introverted space that may recreate a small fragment of nature, a delimited and secluded space that becomes the stage for everyday life. And which, at the same time, grants the independence of the private parts of the building from the public space.

\section{PERMANENCE OF THE PATIO}

The persistence of the patio in Barcelona's urban architecture, despite the changes in the use of the building in which it is located, proves the significance of this first-rate element both as a space and structural configurator. This permanence occurs in buildings that correspond to a very broad time framework, ranging from the 11 th century to the 20 th century. 
The origin of the Barcelona patios that have been preserved over time corresponds to a wide variety of typologies: detached palace houses, town houses, apartment blocks, religious buildings, barracks, schools, offices, industries and facilities. Such buildings were initially erected to meet specific functional needs, but they have evolved and modified their interior layouts to a certain extent. In contrast, the structure of the patio and its connections with the staircase and galleries or corridors, have remained unchanged and have favoured a relative preservation of the spatial organisation of the building.

\section{PATIO AND URBAN FABRIC}

In Barcelona, the patio has a special relevance in denser urban fabrics as it is an element of clearance that provides hygienic conditions to buildings set in narrow and deep plots whose inner rooms need this space to provide a connection with the open air. For this reason, a large number of patio buildings are preserved in Ciutat Vella district, despite the diversification of uses they have undergone over the centuries.

Statistical data can be drawn from the 571 reused buildings in Barcelona listed and documented in the Atlas. ${ }^{1}$ It can be noted that there is a greater number of reused buildings that preserve the courtyard in the most compact urban fabrics. Out of the 571 registered buildings, 171 have at least one patio that has preserved its original features with the changes of use, representing a 29 percent of cases - almost a third of the total. This scenario shows the relevance of this element in maintaining the structural characteristics of a building over time,

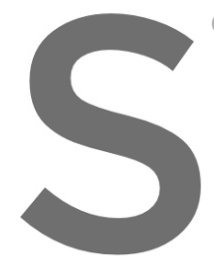
especially in high-densit.
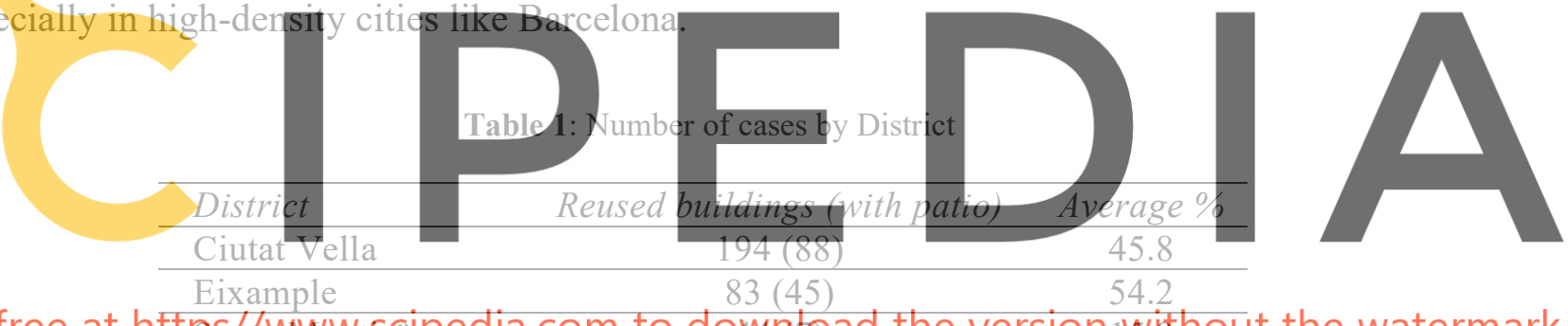

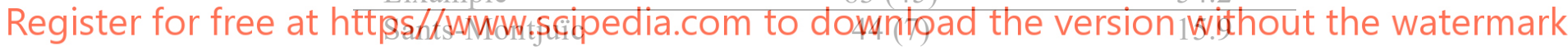

\begin{tabular}{lcc}
\hline Les Corts & $29(4)$ & 13.7 \\
\hline Sarrià-Sant Gervasi & $95(7)$ & 7.3 \\
\hline Gràcia & $25(4)$ & 16.0 \\
\hline Horta-Guinardó & $47(3)$ & 6.4 \\
\hline Nou Barris & $8(2)$ & 25.0 \\
\hline Sant Andreu & $21(1)$ & 4.7 \\
\hline Sant Martí & $43(8)$ & 18.6 \\
\hline
\end{tabular}

However, the dissemination by district is uneven (Table I). The evidence that patios in Ciutat Vella are maintained in most cases has already been mentioned. In addition, the significant number of reused buildings with a patio in the Eixample district may be the result of the emphasis given by Ildefons Cerdà to hygiene issues in order to provide ventilation and sunlight to the dwellings. Due to the building compacity, most of the constructions in the Eixample have one or more inner patios - some of them sheltered by a skylight to house a central staircase that tend to remain in place when the function changes. Yet the buildings located in less dense

\footnotetext{
${ }^{1}$ The Atlas gathers a total of 1,464 currently existing buildings that have changed use at least once during their lifetimes. Of these, a sound amount of documentary detail is available in 571 cases to illustrate their original structure and discuss the transformation processes they have undergone.
} 
urban fabrics, and even those located in garden cities, seldom use the courtyard as a key element in the internal structure of rooms. And if they do, it is in unique facilities or buildings. Such is the case of districts like Sarrià-Sant Gervasi, or Horta-Guinardó.

\section{SCENARIOS AND CASE STUDIES}

The Atlas describes thirteen situations in which the plays a specific role in the change of use. These situations are determined by two factors: the typology of the patio and the modifications occurred with the new activity. On this basis, the following five basic categories can be highlighted:

1. Noble patios of medieval buildings and later reinterpretations of the $19^{\text {th }}$ and $20^{\text {th }}$ centuries, mostly located in Ciutat Vella and Eixample districts. They are part of the entrance system to noble houses or urban palaces. They maintain a structural function by means of bearing walls, although some of the patios - halfway through the cloister - have an inner section of pillars or columns on the ground floor.

2. Cloisters that organise the central void of a variety of buildings, from the Middle Ages to the 19th century, with a main function in the distribution of activity and which, on a structural level, are bounded by a perimeter gallery defined by an outer wall and an inner arcade supported by columns or piers.

. Patios of apartment buildings involved in the access system, lighting and ventilation of multi-storey constructions basically erected in the Eixample district from the $19^{\text {th }}$ century to the present day. Usually defined by brickwork bearing walls, they maintain a basic structurai function, often as a sh

4. Industrial courtyart nethe

. Other courtyard

part of a built comple

developed over time
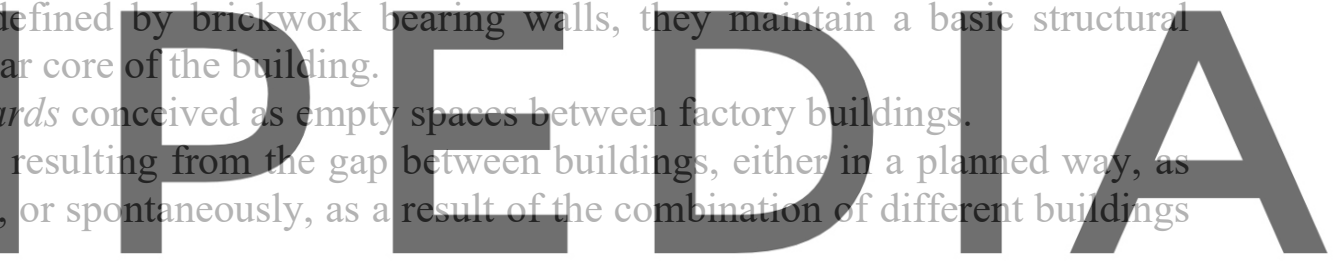

Out of these five categories, this paper focuses on the first three, as they are the most

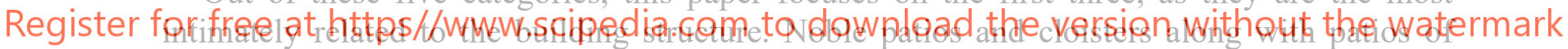

apartment buildings constitute the core of their corresponding constructions, to the extent that their identity as primary structural elements and their ability to organize the activity of the building cannot be considered separately, especially when a strategic change of use is envisaged.

Regarding these categories, two basic scenarios are worth mentioning when it comes to adaptive reuse: a) Conservation of structure and function and b) Preservation of the structure, but alterations of the function. Accordingly, six combinations between the three categories considered and the two basic scenarios are possible. Each of the combinations can be illustrated with outstanding cases and by listing other examples in which a similar situation occurs.

\subsection{Noble patios that preserve structure and functions}

Case study 1: Casa de l'Ardiaca, 1190. Association of Lawyers of Barcelona, 1895 (Lluis Domènech i Montaner). Historical Archive of Barcelona, 1920 (Josep Goday) and 1998 (Lluís Doménch, Roser Amadó).

The patio of L'Ardiaca has special characteristics that distinguish it from the rest of the archetypal palatial patios. Firstly, it is elevated above street level and is accessed by steps that extend into the public space. At the same time, as the plot is not very deep, the main bay of the house is located adjacent to the Roman wall and there is no space left for a central patio. Its 
position is shifted, it is attached directly to the enclosure's urban wall and the entrance door opens directly onto the street. This marginal situation gives it a hybrid functional and spatial character, as it acts simultaneously as a vestibule and a patio. In spite of this, it preserves the morphological characteristics of any noble patio: a perimeter deambulatory and a main staircase that, from one of its sides, leads to the first floor.

These original features have been maintained over the centuries, despite the changes in use and the successive extensions to the adjacent buildings. The various alterations have mainly affected secondary vertical communication nuclei, which have moved from a central position to the space freed up by the rooms formerly attached to the Decuman Tower. The position of the lift has also moved the axis of circulation to an area parallel to the wall, thus clearing a larger space for the archive's reading rooms.

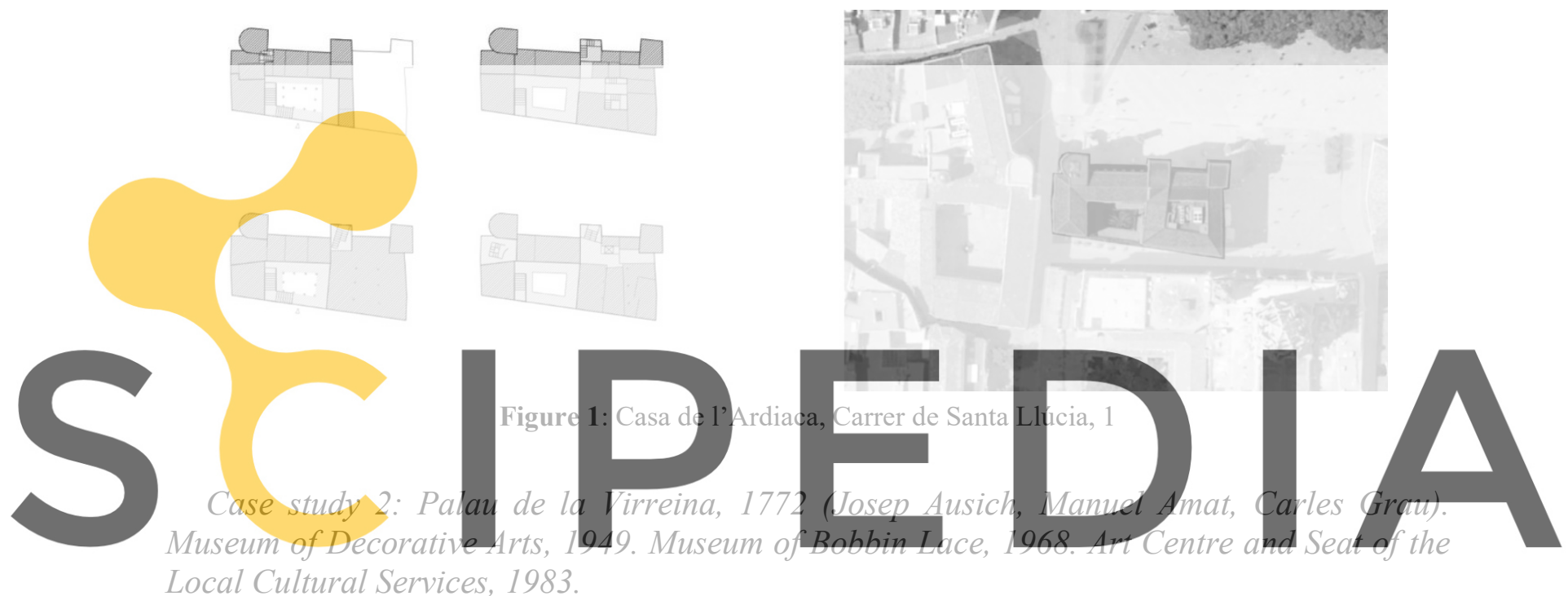

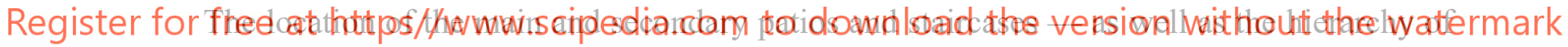
circulation and connection elements - have been maintained over time, despite the various changes in use. Both the main patio and a second smaller one are located in the central bay of the wing adjacent to Les Rambles. As they are aligned with the axis of the main entrance, the presence of these 'wells of light' can be perceived from the street, particularly since the recent opening of a second entrance from the back alley. They thus become reference elements both from the outside and from all the internal areas of the building. The smart geometric layout of the floor plan places them in an eccentric position with respect to the rest of rooms on the plot, but in a central position with respect to their depth.

On the upper floors, the main courtyard is surrounded by a glassed-in gallery that opens up to the rooms on La Rambla, to the back rooms and to the side corridors with service rooms and secondary staircases. Recent alterations in use have placed the lift shafts in this bay. The current use of the museum, together with the relevant placement of the lifts, coexists perfectly with the original structure of the palace, with hardly any modification to the original circulation or the load-bearing elements. In addition, the large gallery is optimised as a complementary exhibition space to the displays in the other noble rooms. 

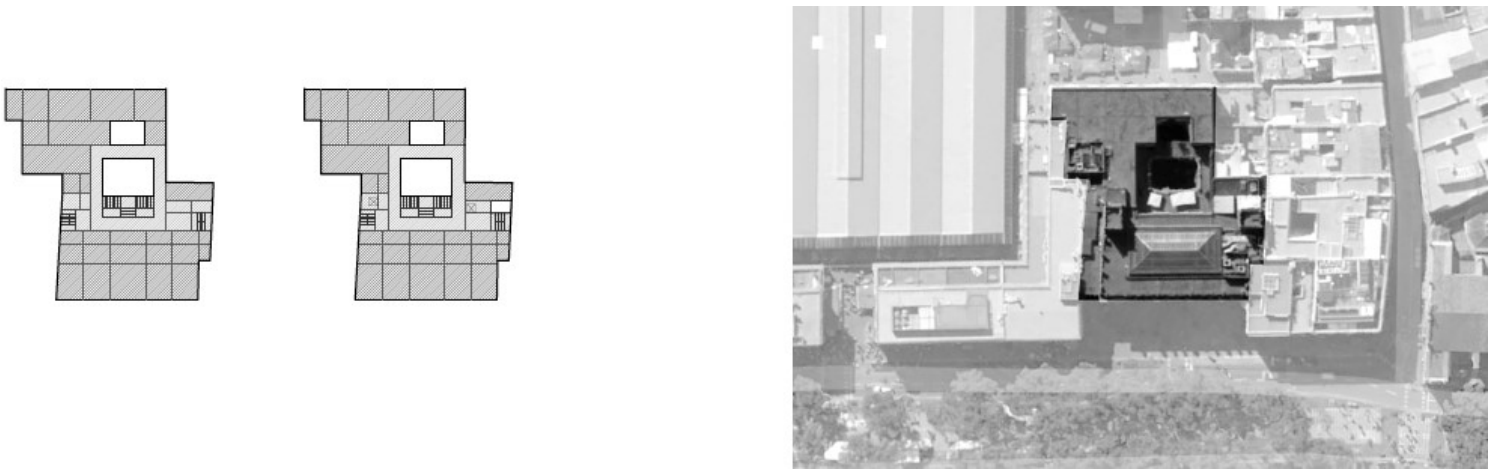

Figure 2: Palau de la Virreina, Les Rambles, 99

Other documented cases:

1. Palau in Carrer de Montcada 18, 1450. Nursery School Nen Jesús, 1899 and 2009

2. Palau Cervelló-Giudice, 1490 (circa). Maeght Art Gallery, 1974. Gaspar Art Foundation, 2015.

3. Palau Centelles, 1517. Barcelona Philharmonic Society, 1847. Advisory Council of the Generalitat of Catalonia, 1980. Headquarters of the IEA, Institute of Autonomic Studies, 2002 (Soler-Farriol).

4. Palau Bassols, 1550 (circa). Royal Artistic Circle, 1959

5. Palau Moxó, 1770 (Francesc Mestres). Museum - Restaurant-Housing, 2015

6. Palau Moja, 1774 (Jose

of Cultural Heritage,

7. Palauet Alòs, 1807

Association, 1940. Apa

8. Reial Acadèmia de $B$
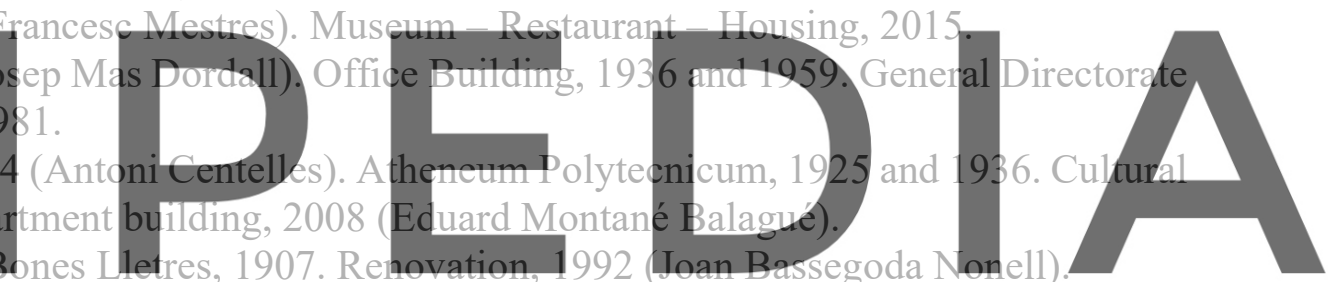

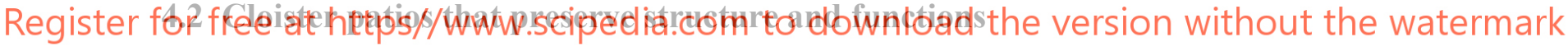

Case study 1: Palau del Lloctinent, 1557 (Antoni Carbonell). Seat of the Archive of the

Crown of Aragon, 1836 and 2006 (Lluis Domènech, Roser Amadó).

Despite the interior changes undergone over the centuries in the four bays that structure the building, the main patio, of generous dimensions, remains the central articulator of the palace. The same applies to the adjacent staircase, located in the bay adjacent to the only party wall that connects the building with the rest of the constructions in the complex.

On the ground floor, an ambulatory open to the cloister through four bell arches connects the two entrances currently facing each other: one opens onto the Plaça del Rei and the other onto Carrer dels Comptes. On the first floor, the gallery built with Tuscan-style carved stone arches supported by balusters continues to serve as a connection and distribution of the rooms organized around it. Two elevators placed in pieces near the staircase, solve the current requirements of accessibility without interfering with the original circulations. 

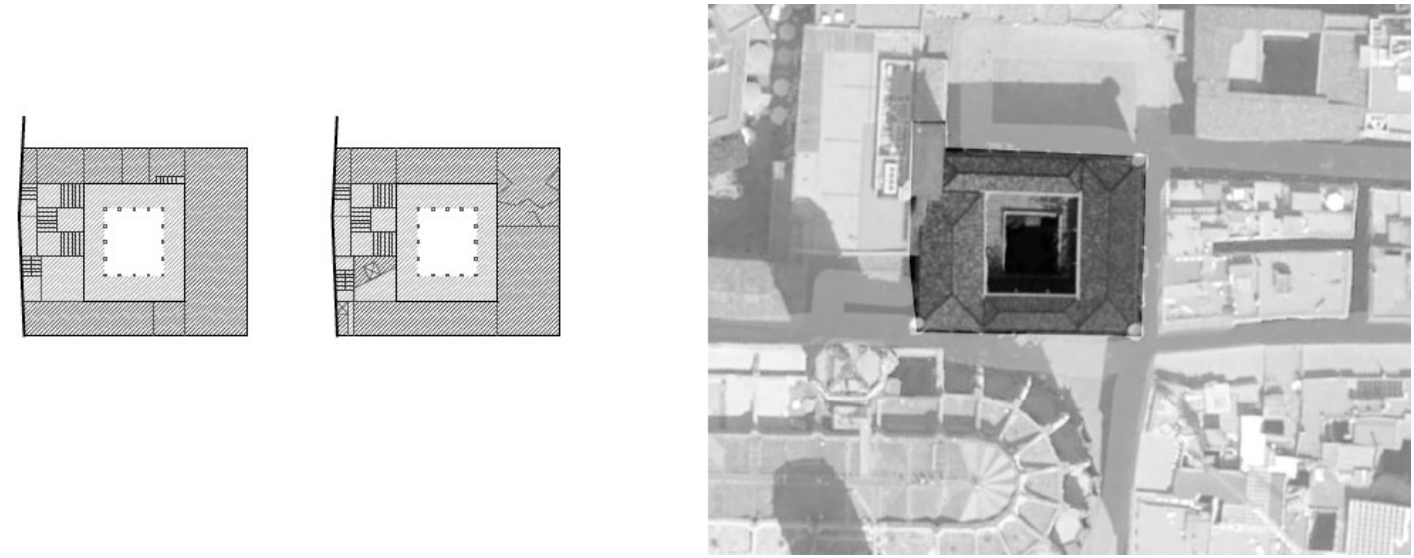

Figure 3: Palau del Lloctinent, Carrer dels Comtes, 2

Case study 2: Convent of La Mercè, 1590. Headquarters of the General Capitaincy of Barcelona, 1845 and 1920.

As a result of the Law of Confiscation, issued in 1836, the convent was converted from religious to military use. Even so, the original layout of the building remains practically intact. The convent was initially organised into two areas: a section containing a large cloister, the main entrance from Carrer de la Mercè, the most relevant rooms and the main staircase; and an equivalent section of service rooms, refectory and kitchen on the ground floor, with a secondary entrance on the same street and another secondary staircase, bedrooms, a small colurtyard and other private rooms on $\mathrm{t}$ church by a covered bric

With the change of use, the dichotomy betw the large cloister, the se
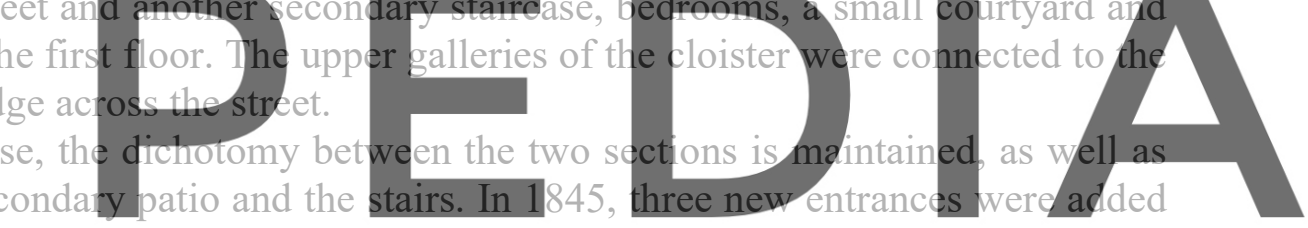

to the two original doors from Carrer de la Mercè, from the recently developed Passeig de

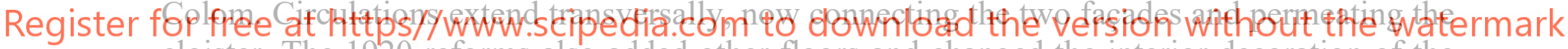
cloister. The 1920 reforms also added other floors and changed the interior decoration of the rooms.
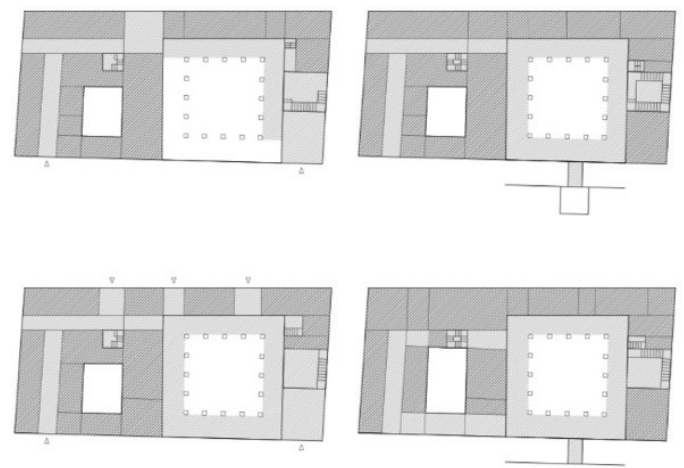

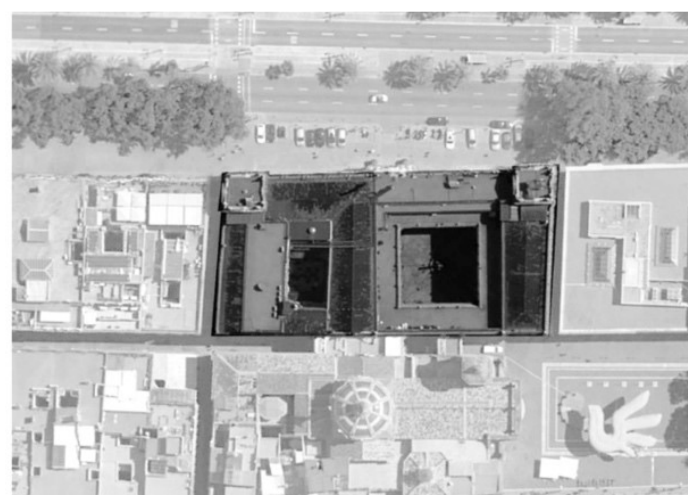

Figure 4: Convent of La Mercè, Passeig de Colom, 14

Other documented cases:

1. Casa de Convalescència (House of Convalescence), 1629. Institute of Catalan Studies, 1931. Barcelona Provincial Council, 1939. Institute of Catalan Studies, 1982.

2. Casa de la Caritat (House of Charity) - Pati Manning, $18^{\text {th }}$ century. Center for Cultural 
Studies and Resources CERC, 1981 and 1995.

3. Former Customs House, 1790 (Conde de Roncali). Spanish Government Delegation, 1902. End of activity, 2008.

4. Llars Mundet Llevant Pavilion, 1927 (Joan Rubió i Bellver). Concentration Camp, 1939. Old Ladies' Home, 1982 (Manuel Baldrich). Llevant Building, Mundet University Campus, 1996 (F. Labastida, M. Ribas).

\subsection{Patios of apartment buildings that preserve structure and functions}

Case study 1: Caixa de Barcelona Headquarters, 1899 (August Font $i$ Carreras). Directorate General of Contentious Affairs, 1998 (TAC Architects).

The building — with facades facing four streets - has a trapezoid-shaped floor plan from which a portion has been subtracted in order to regularize the geometry of the Plaça de Sant Jaume. The central space, visually connected with the entrance axis from Carrer de la Ciutat, limits at one of its angles with the noble staircase, which is shifted from the access line to adapt to the irregularity of the plot. The building has also two secondary staircases located at the two corners of Carrer Jaume I. This central space serves as a hall on the ground floor, as it is covered at the height of the first floor by a skylight.

In one of the renovations the patio was occupied by a suspended auditorium located on the upper floor. In the last intervention, the auditorium was removed, recovering the original qualities of the central space and bringing light and ventilation back to the lower floors. The

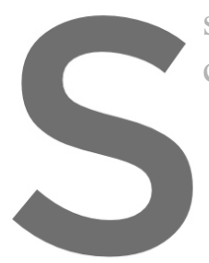
core of lifts that do not a

Register for free at https//www.scipedia.com to download the version without the watermark
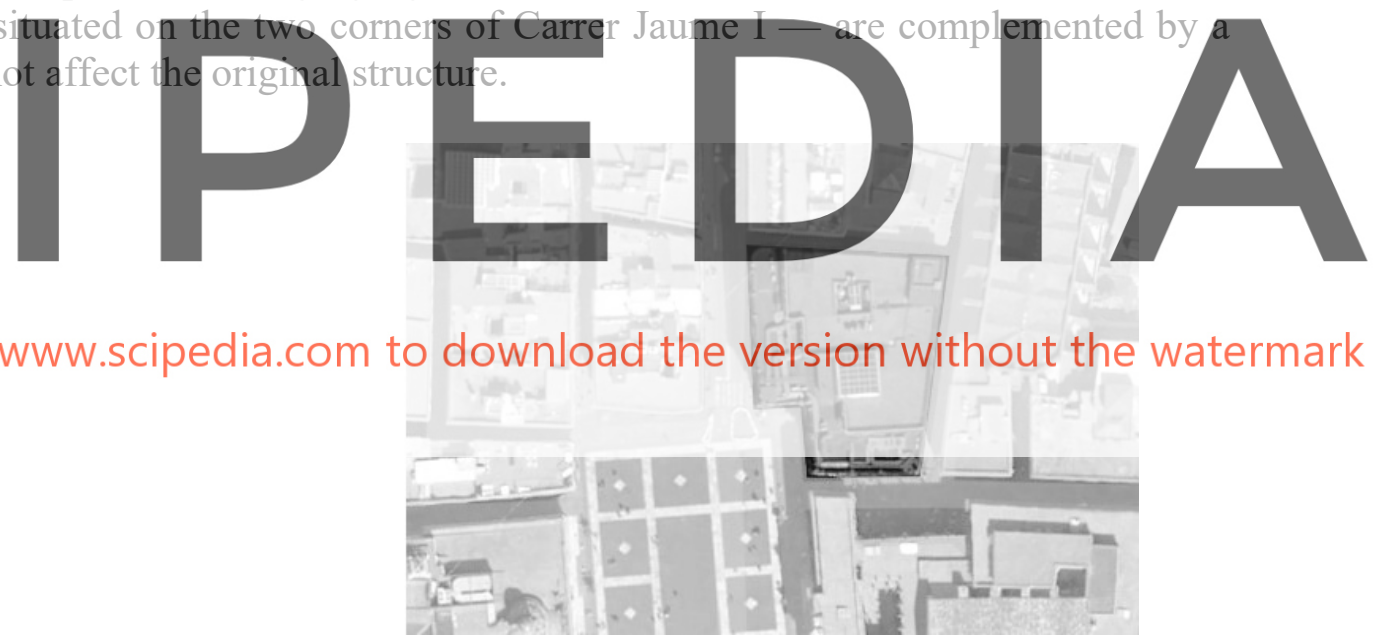

Figure 5: Caixa de Barcelona Headquarters, Plaça de Sant Jaume, 7-8

Other documented cases:

1. Community of Dominican Sisters, 1868 (Francisco de Paula Villar Lozano). Elisabets University Housing (Sergi Burgada Rodríguez).

2. Transmediterranean Ship Company, 1917 (Juli Maria Fossas). Department of Universities and Research of the Generalitat of Catalonia, 1994.

3. Provincial Savings Bank Offices, 1956 and 1962 (Robert Terradas i Via). Apartment building, 2014.

\subsection{Noble patios that preserve structure but modify functions}

Case study 1: Casa Macaya, 1899. Architect: Josep Puig i Cadafalch. Institute for Deaf- 
Mutes, 1949. 'La Caixa' Cultural Centre, 1988. Architect: Eugeni Bach \& Gabriel Mora.

The building is a former urban palace, organized in four bays around a central patio with a roofed staircase leading to the first floor. The wide façade bay contains, on the upper floors, the rooms of larger dimension and, on the ground floor, the access to the building located off the axis of the courtyard. The double back bay is formed by equivalent rooms - which ventilate and illuminate through the backyard - and by smaller rooms that accompany the secondary staircase that gives access to all the floors.

The changes in use have preserved the main access, through a side entrance hall that, after the first two bays, opens out onto the large patio. Both the noble staircase and the secondary staircase have remained intact. The main renovations affecting the circulations occur in one of the two secondary patios that originally ventilated and illuminated the side rooms. With the latest alteration, this space has been used to house a third staircase and two lifts. This has displaced the original circulation around the main patio towards the bay that connects with the new stairs and lifts.

The partition walls around the main patio have been removed, causing the disappearance of the passageway around it and modifying circulations. At the same time the patio has been covered by a skylight.
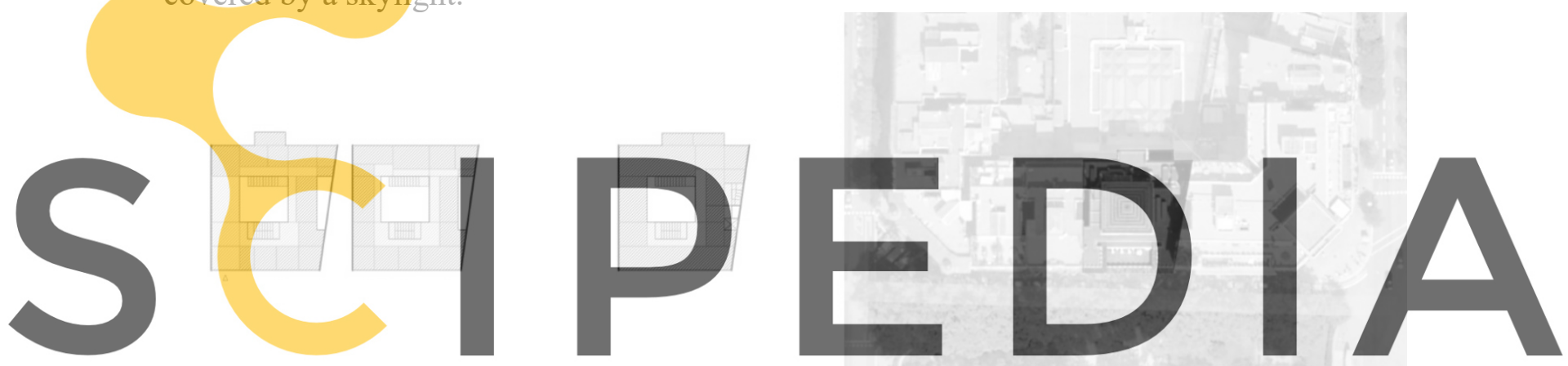

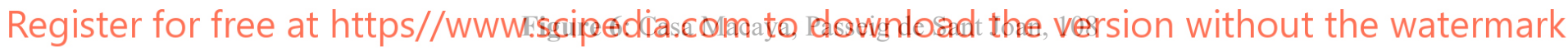

Other documenied cases.

1. Palau Mercader, 1550. Cercle Artístic de Sant Lluc, 2014 (Portal Ballber Architects).

2. Palau Mornau-Palau Nadal, 1590 (circa). Cannabis Museum.

3. Palau Gomis, 1750. European Museum of Modern Art, 2011 (Josep Infiesta, Jordi Garcés).

4. Urban House, 1770. Cercle Barcelonés de Sant Josep, 1879 (Joan Martorell). 'Antic Teatre'

Space of Creation, 2003.

5. Palau Sabassona, 1796 (Josep Francesc Ferrer de Llupià). Ateneu Barcelonès, 1907 and 2011 (Manel Brullet, Mateu Barba).

6. Palau Dou, 1818 (Antoni Celles Azcona). Cervantes School and High School, 1940 (Juan Antonio Zaragoza).

7. Casa de les Altures, 1890 (Enric Figueres). Summer Camp House, 1936. Hydrological Research Institute and Headquarters of theHorta-Guinardó District, 1989 (Víctor Argentí).

8. Palau Baró de Quadras, 1904 (Josep Puig i Cadafalch). Music Museum, 1980. Asia House. Ramon Llull Institute, 2003.

9. Pérez Samanillo House, 1910 (J.J. Hervás). 'Círculo Ecuestre' Club, 1950 (Raimon Duran i Reynals). 


\subsection{Cloister patios that preserve structure but modify functions}

Case study: Convent of Santa Monica, 1635. Santa Monica Art Centre, 1987 (Albert Viaplana, Helio Piñón).

The convent - the only one left standing in the final section of the Ramblas after the Law of Confiscation of 1836 - used to organise all its chambers around a large square cloister with a central well. On the ground floor, the galleries, with Roman arches on Doric pilasters, connected the rooms located in the four adjacent bays. On the upper floors, balconies or windows opened onto the cloister. The other rooms in the complex adapted to the unevenness of the plot, so that the geometry of the cloister was left regular. The cloister communicated laterally with a still existing church that was also accessed from Les Rambles through a narthex, while the entrance to the convent was from the Carrer del Portal de Santa Madrona.

The 1987 renovation redefines the formal and functional logic of the original cloister by erecting two parallel walls that divide its centre into three parts. This fact, together with the new roof, totally changes its open character and its perimetral circulation. On the ground floor, the cloister becomes a walkable exhibition area. In contrast, on the upper floors, the intercommunicating rooms continue to open with balconies or windows to this great central empty space, now interrupted by thick concrete walls. The original entrance to the convent is preserved but a new main access is added from Les Rambles directly to the first floor through a wide ramp that also serves as a large public balcony. The relationship with the church which currently functions as a parish — is broken. Despite these changes, the building

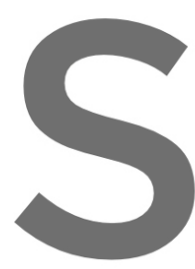
maintains the location convent, even though internal
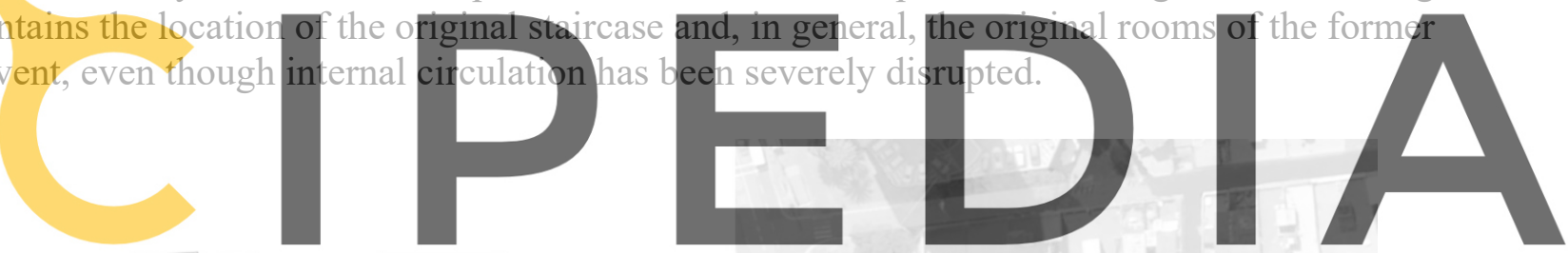

Register for free at https//www.scipedia.com to download the version without the watermark
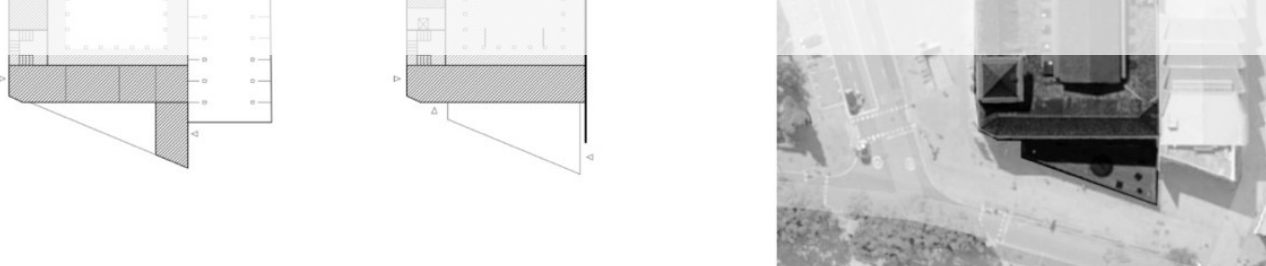

Figure 7: Convent of Santa Monica, Les Rambles, 7

Other documented cases:

1. Convent of Sant Agustí Vell, 1347. Sant Agustí Barracks, 1738. Sant Agustí Vell Civic Centre, 1994 (Antoni de Moragas). Museum and Photographic Archive, 1994.

2. Convent of the Franciscan College of Sant Bonaventura, 1652. Hotel Orient, 1881 (Eduard Fontseré) and 2001 (Robert Brufau).

3. Palace of the Governor, Ciutadella Park, 1718 (Joris Prosper van Verboom). Fire Station, 1932. Verdaguer High School, 1932.

4. Casa de la Caritat (House of Charity), 1736, 1804, 1861 (Josep Oriol Mestres), 1912 (Josep Goday). Centre of Contemporary Culture of Barcelona CCCB, 1991-1995 (A. Viaplana, H. Piñón, R. Mercadé). 


\subsection{Patios of apartment buildings that preserve structure but modify functions}

Case study: Joan Puig House, 1872 (Pere Bassegoda Mateu). Warehouses and Offices. Hotel, 1997 (José Luis Sayos).

The late $19^{\text {th }}$ century building was organised around a main patio with a noble staircase, located in the fourth bay of the building, closer to the backyard than to the façade. Four secondary patios, two of which had service staircases, completed the ventilation and lighting of the entire floor. The building's circulation was basically around the main patio, connecting the various rooms directly to each other, in an "Italian-style" layout.

With the latest conversion to a hotel, the noble patio and the staircase to the main floor have been maintained, but two lifts have been added. The rest of the secondary patios are used to ventilate and illuminate some of the new hotel rooms, covering the entire surface of the floors. The service stairs change their configuration but not their position and interlink with each other and with the lifts connected to the main patio through a new network of corridors.
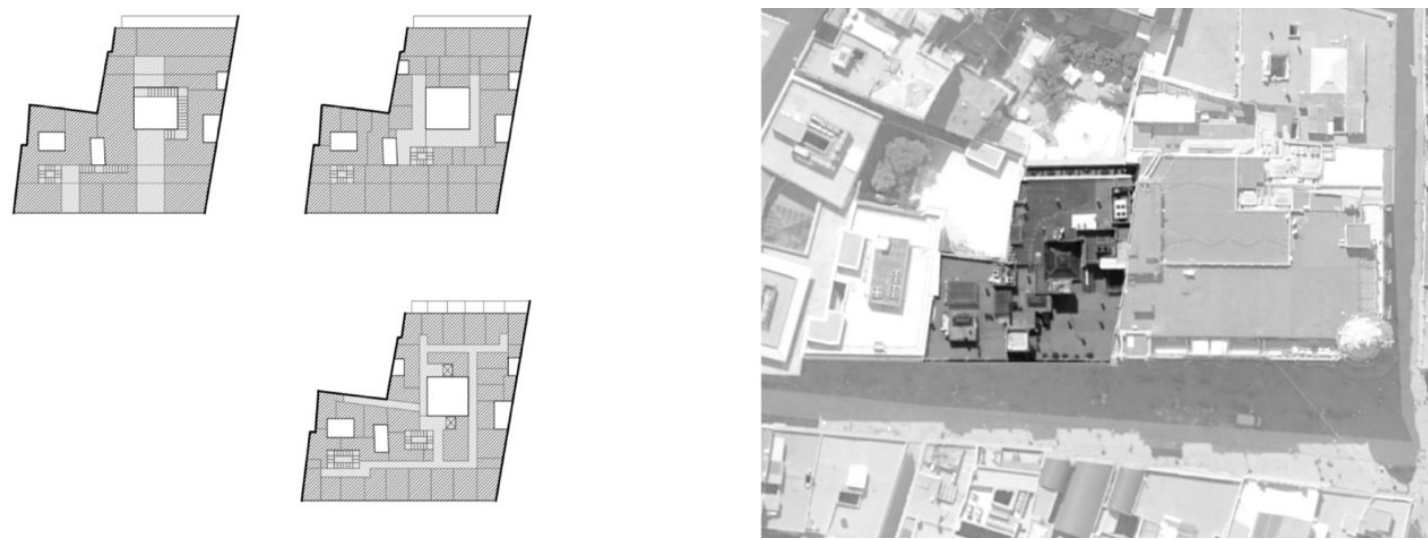

Figure 8: Joan Puig House, Portal de l'Àngel, 15-17

Other documented cases:

1. Apartment building, 1850. Fernando Hostel, 1998 (G. Amigó Buixaderas).

2. Apartment building, 1863 (Narcís Nuet). Hostel, 2010.

3. Joan Serra House, 1867 (Francisco de Paula Villar). 'Las Noticias' and 'El Correo Catalán' Newspaper's Office, 1925. Montecarlo Hotel, 2000 (Lluis Jaumandreu i Anglada).

4. Apartment building, 1870. Cocoon apartaments, 2000 (A\&M arquitectes).

\section{DISCUSSION AND CONCLUSIONS}

The Atlas has been able to classify buildings with a patio according to their structural, organisational, and typological characteristics along with the changes undergone in those fields. Despite the differences initially revealed among those buildings, the research draws conclusions on the understanding of material transformations and changes of use.

On the basis of the study on the evolution of the urban patio and its capacity to adapt, transform and reconfigure when a change of use applies, it is possible to state - in the light of the documented cases - that the patio is an enduring architectural element, because of the combination of both its structural and organizational characteristics. This double potential is also largely responsible for preserving the structural characteristics of the rest of the spaces adjacent to it, even if changes in the functioning and organization of the building occur when 
there is a change of use. Indeed, it could be argued that the enclosing walls of the patio - as they simultaneously belong to such a consistent bearing and functional system - define an area of influence on both sides that has the capacity to persist over time, even when the building undergoes profound transformations.

Thus, the patio - defined as the open-air inner court of a building — is an element that clearly shows the relationship between the supporting structure and its function - understood as the use or activity that takes place in a building. This clear and direct relationship, which also characterises and defines its spatial qualities, is the key to its adaptive capacity and must therefore be carefully considered in future interventions that seek to extend the lifespan of buildings, especially when environmental factors are considered, along with artistic, historical, social and heritage aspects. Public policies should address these processes, by establishing clear and useful criteria to evaluate transformations. Political support is definitely needed to facilitate this scenario [10].

Acknowledgements. This paper is made possible by the funding of the Spanish Ministry of Economy and Competitiveness, through the National R\&D Programme Aimed at the Challenges of Society 2013.

\section{REFERENCES}

[1] Monteys, X., Mària, M., Fuertes, P., Sauquet, R., \& Salvadó, N. (2018) Atlas del aprovechamiento arquitectónico. Estudio crítico de los edificios reutilizados en Barcelona. Barcelona: MINECO, Universitat Politècnica de Catalunya.

[2] Austin, R. L., Woodcock, D. G., Steward, W. C., \& Forrester R. A. (1988). Adative Reuse: Issues and Case Studies in Building Preservation. New York: Van Nostrand Reinhold Company.

[3] Ball, R. (1999). Developers, regeneration and sustainability issues in the reuse of vacant industrial buildings. Building Research \& Information, 27(3), 140-148.

[4] Bon R., Hutchinson K. (2000). Sustainable construction: some economic challenges. Building Research and Information, 28(5/6), 310-4.

[5] Douglas, J. (2006). Building Adaptation, 2nd ed., Burlington: Butterworth-Heinemann.

[6] Bullen, P. A. (2007). Adaptive reuse and sustainibility of commercial buildings. Facilities, 25, 20-31.

[7] Langston, C. A. (2008). The sustainability implications of building adaptive reuse. In CRIOCM 2008 International Research Symposium. Retrieved January 21, 2019 from https://works.bepress.com/craig_langston/1/

[8] Rueda, S. (2018). Carta para el diseño de nuevos desarrollos urbanos y regeneración de los existentes. Congreso Post-Habitat III. Retrieved December 15, 2018 from Barcelona.http://www.cartaurbanismoecosistemico.com/

[9] Díaz Recasens, G. (1992). Recurrencia y herencia del patio en el movimiento moderno. Sevilla: Universidad de Sevilla.

[10] Yung, E. H., \& Chan, E. H. (2012) Implementation Challenges to the Adaptive Reuse of Heritage Buildings. Towards the Goals of Sustainable, Low Carbon Cities. Habitat international, 36(3), 352-361. 